\title{
The Effect on Neutronic Calculations of Certain Alternative Fuels in a Boiling Water Reactor by Using MCNPX Monte Carlo Method
}

\author{
M. GÜnAY ${ }^{a, *}$, V.H. SAnchez Espinoza ${ }^{b}$ And A. TravleEV ${ }^{b}$ \\ ${ }^{a}$ İnönü University, Physics Department, Malatya, Turkey \\ ${ }^{b}$ Karlsruhe Institute of Technology, Institute for Neutron Physics and Reactor Technology (INR), \\ Karlsruhe, Germany
}

We were studying on the modeling of boiling water reactor fuel assemblies at pin-by-pin level by using Monte Carlo method. The designed boiling water reactor system is cylinder, and the radius of the cylinder is $228 \mathrm{~cm}$. The total active core height is $315.79 \mathrm{~cm}$. The reactor core was divided into the square lattice $7 \times 7$ type with a constant pitch of $30 \mathrm{~cm}$. The core was surrounded with the reflector. The reflector was surrounded by SS316LN ferritic steel with width of $3 \mathrm{~cm}$. The mixtures $0.2-1 \% \mathrm{PuF}_{4}$ and $\mathrm{PuO}_{2}$ were used as fuel. In this study, the effect on the neutronic calculations of $\mathrm{PuF}_{4}$ and $\mathrm{PuO}_{2}$ fuels was investigated in the designed boiling water reactor system. There were calculated $k_{\text {eff }}$, heat deposition and the fission energy in the designed boiling water reactor system. The three-dimensional (3D) modelling of the reactor core and fuel assembly into the designed boiling water reactor system was performed by using MCNPX-2.7.0 Monte Carlo method and the ENDF/B nuclear data library.

DOI: 10.12693/APhysPolA.128.B-110

PACS: 28.41.-i, 28.41.Ak

\section{Introduction}

The light water reactors (LWRs) - the most common reactor type — was developed during 1950s for energy production. The boiling water reactor (BWR) has different design of LWRs fundamentally based on pressure. The waste management required as a result of fuel burning to generate energy from traditional nuclear reactors is an important problem. Transformations of nuclear waste into stable and short-lived isotopes through nuclear reactions are possible solutions. Moreover, traditional reactors use only a very small amount of natural uranium in enriched nuclear fuel, leaving the remainder as radioactive waste. Consequently, it is estimated that nuclear fuel will become scarce in future [1-4].

A substantial amount of spent fuel grade (SFG) plutonium $(\mathrm{Pu})$ from current nuclear reactors has been stored for future use. Isotopic distribution of SFG-Pu has composition $2.4 \%{ }^{238} \mathrm{Pu}, 58.5 \%{ }^{239} \mathrm{Pu}, 24 \%{ }^{240} \mathrm{Pu}$, $11.2 \%{ }^{241} \mathrm{Pu}$ and $3.9 \%{ }^{242} \mathrm{Pu}$ [5]. SFG-Pu is valuable, but would be dangerous if misused. Therefore, radioactive materials with a plutonium additive have been used in this study to reduce the amount of spent fuel grade plutonium used.

We have designed a BWR system using the mixtures $0.2-1 \%$ SFG-PuF 4 and $\mathrm{SFG}-\mathrm{PuO}_{2}$ as fuel. The effect of the mixtures rates to three-dimensional neutronic measurements, such as $k_{\text {eff }}$, heat deposition and

\footnotetext{
*corresponding author; e-mail: mehtap.gunay@inonu.edu.tr
}

the fission energy, have been calculated in the designed BWR system MCNPX-2.7.0 Monte Carlo code and ENDF/B-VII.0 nuclear data library is used for the three-dimensional (3D) modelling of the reactor core and fuel assembly into the designed BWR system.

\section{Method}

\subsection{BWR core and fuel assembly geometry}

The designed BWR system is cylinder, and the radius of the cylinder is $228 \mathrm{~cm}$. The total active core height is $315.79 \mathrm{~cm}$. The reactor core was divided into the square lattice $7 \times 7$ type with a constant pitch of $30 \mathrm{~cm}$. The core was surrounded with the reflector. The outboard side of reflector was surrounded by SS316LN ferritic steel with width of $3 \mathrm{~cm}$. The core design of the designed BWR system is shown in Fig. 1.

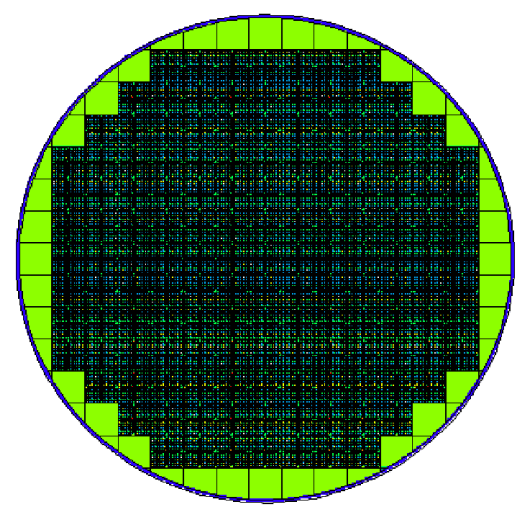

Fig. 1. The core design of the designed BWR system. 


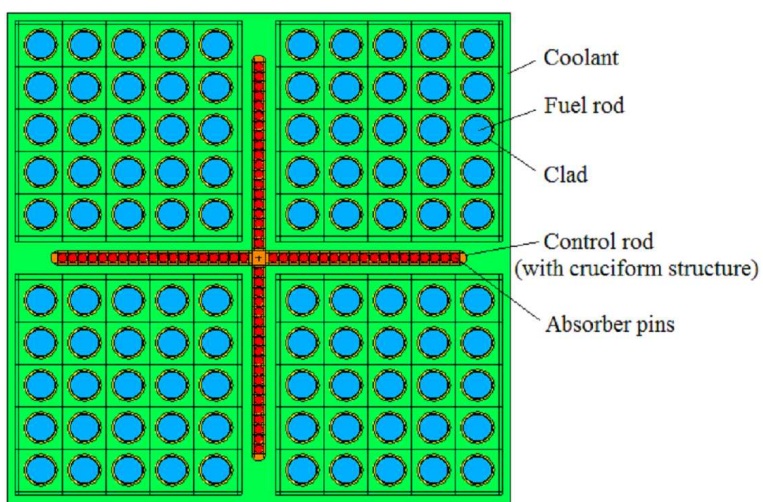

Fig. 2. A fuel assembly in the core of the designed BWR system.

The core consists of 145 fuel assemblies, surrounded with approximately 35 reflector assemblies. The every square lattice for the fuel rods was separated to four small square zones with a size of $13 \mathrm{~cm}$. The every small square zone was divided into the small square lattices $5 \times 5$ type with a constant pitch of $2.6 \mathrm{~cm}$. The square lattice (fuel assembly) in the core of the designed BWR system is shown in Fig. 2.

Fuel pins were put in cylinder shape into the small square lattices. The fuel pins were created from the fuel rod, gap and clad. The fuel rod radius was $0.8454 \mathrm{~cm}$ and the clad radius was $0.9978 \mathrm{~cm}$ in the fuel pins. The gap with width of $0.0352 \mathrm{~cm}$ in between the fuel rod and the clad was made. The pin cell geometry in the small square lattice of the designed BWR system is shown in Fig. 3.

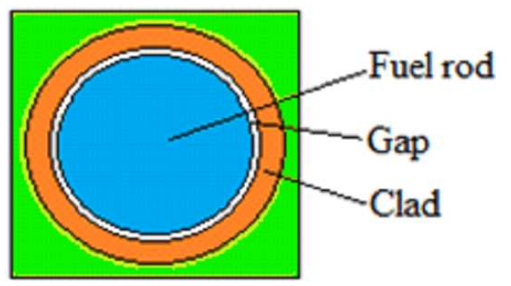

Fig. 3. Pin cell geometry.

25 fuel rods were put inside every small square lattice and 100 fuel rods - inside every square lattice. Thus, total 14500 fuel rods were put in the designed BWR system. The control rods providing reactivity control were put inside the cruciform in between four small square lattices. The blade radius of the control rod is $0.41 \mathrm{~cm}$ and the blade half length is $12 \mathrm{~cm}$. The absorber pins were made in cylinder shape into the cruciform (Fig. 2). The absorber pins were used as $0.28 \mathrm{~cm}$ radius. Total 145 cruciforms in the designed BWR system were used. In every cruciform total 76 absorber pins were used (19 per wing). Thus, total 11020 absorber pins in the designed BWR system were used.

The graphite was used in the reflector surrounding the core. The reflector was surrounded by SS316LN ferritic steel. It was filled by $0.2-1 \% \mathrm{PuF}_{4}$ and $\mathrm{PuO}_{2}$ the fuel rod and Zircaloy-2 the clad. $\mathrm{H}_{2} \mathrm{O}$ was used as coolant in the designed BWR system. In the cruciform there was used Type-304 stainless steel as structural material. The control rods were filled by $\mathrm{B}_{4} \mathrm{C}$.

\subsection{Numerical calculations}

Nuclear reaction cross-sections can be obtained in three different ways: experimental measurements, theoretical calculations, and evaluated nuclear data files (ENDFs). For wide ranges of energy, measuring the cross-sections for all isotopes in the periodic table is unfeasible both physically and economically. Therefore, model calculations play an important role in evaluation of nuclear data $[6,7]$.

Evaluated nuclear data file $\mathrm{ENDF} / \mathrm{B}$ has been first developed in USA in 1968. New versions are published periodically following large-scale investigations and additional research. ENDF/B-VII libraries, which are used for theoretical calculations in MCNPX, include nuclear data from $10^{-11}$ to $20 \mathrm{MeV}$ for all isotopes and up to $150 \mathrm{MeV}$ for certain isotopes [8,9]. The data of the ENDF/B-VII and also EXFOR libraries are very important for theoretical calculations [10].

Monte Carlo method is generally used because of the complex three-dimensional configuration of materials and many physics problems of deterministic methods. The MCNPX transport code uses standard cross-section libraries compiled from ENDF/B for neutron, proton and photonuclear interactions. The three-dimensional (3D) modelling of the reactor core and fuel assembly into the designed BWR system was performed by using MCNPX2.7.0 Monte Carlo method and the ENDF/B-VII.0 nuclear data library.

\section{Conclusion}

In this study, we investigated the effect of $\mathrm{PuF}_{4}$ and $\mathrm{PuO}_{2}$ fuels in the designed BWR system on the threedimensional neutronic measurements such as $k_{\text {eff }}$, heat deposition and the fission energy using the ENDF/BVII.0 nuclear data library. In study, the fuels $0.2-1 \%$ SFG-PuF 4 and $\mathrm{SFG}-\mathrm{PuO}_{2}$ were used to investigate neutronic performance of the designed BWR system.

The effective multiplication constant must be $k_{\text {eff }} \leq 1$ in the designed BWR system to avoid the critical accident. Figure 4 shows that there is a increase in the $k_{\text {eff }}$ values with increasing fuel content for $\mathrm{SFG}-\mathrm{PuF}_{4}$ and $\mathrm{SFG}-\mathrm{PuO}_{2}$ in the designed BWR system. In Fig. 4, the $k_{\text {eff }}$ values calculated with fuels $\mathrm{SFG}-\mathrm{PuF}_{4}$ and SFG$\mathrm{PuO}_{2}$ are $k_{\text {eff }} \leq 1$ for $0.2-1 \%$ SFG-PuF 4 and SFG-PuO ${ }_{2}$. From Fig. 4 , the $k_{\text {eff }}$ value for the fuel $1 \%$ SFG-PuO gives the largest effect and $0.2 \% \mathrm{SFG} \mathrm{PuF}_{4}$ gives the smallest effect when used in the designed BWR system.

Figure 5 shows that fission energy values increases with increasing fuel content of $\mathrm{SFG}_{-} \mathrm{PuF}_{4}$ and $\mathrm{SFG}-\mathrm{PuO}_{2}$ fuels. From Fig. 5, $1 \%$ SFG-PuO $\mathrm{Su}_{2}$ gives the largest effect and $0.2 \% \mathrm{SFG}_{-} \mathrm{PuF}_{4}$ gives the smallest effect to fission energy. 


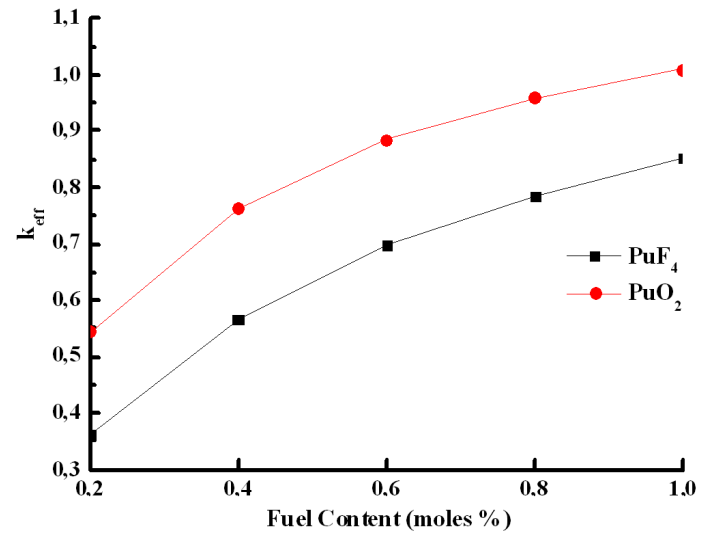

Fig. 4. The $k_{\text {eff }}$ values of the fuel components SFG$\mathrm{PuF}_{4}$ and $\mathrm{SFG}-\mathrm{PuO}_{2}$ in the BWR system.

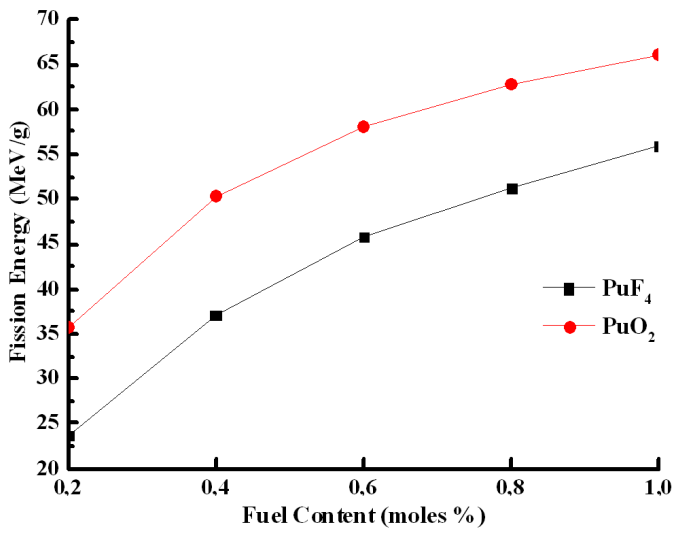

Fig. 5. The fission energy values of the fuel components $\mathrm{SFG}-\mathrm{PuF}_{4}$ and $\mathrm{SFG}-\mathrm{PuO}_{2}$ in the BWR system.

In Tables I and II there were provided results of the heat deposition rate in all the fuel, water, clad, cruciform, core region of the fuel components $\mathrm{SFG}-\mathrm{PuF}_{4}$ and SFG$\mathrm{PuO}_{2}$. Tables I and II show that the total heat deposition rate increases for increase of fission reaction rate with increase of fuel contents. In Table I there was founded that the total heat deposition more than average $15 \%$ in fuel, $8 \%$ in water, $4 \%$ in clad and $3 \%$ in absorbers were released for $0.2-1 \% \mathrm{SFG}_{-} \mathrm{PuF}_{4}$ fuel. In Table II there was

TABLE I

The contribution of each zone in the BWR system to the integrated heat deposition rate $(\mathrm{MeV} / \mathrm{g})$ for the fuel components $\mathrm{SFG}_{-} \mathrm{PuF}_{4}$.

\begin{tabular}{c|c|c|c|c|c}
\hline \hline \multirow{2}{*}{ Zones } & \multicolumn{5}{|c}{$\mathrm{PuF}_{4}[\mathrm{~mol} \%]$} \\
\cline { 2 - 6 } & 0.2 & 0.4 & 0.6 & 0.8 & 1 \\
\hline fuel & 21.99 & 34.42 & 42.48 & 47.65 & 52.11 \\
water & 3.03 & 3.23 & 3.36 & 3.43 & 3.49 \\
clad & 1.29 & 1.49 & 1.61 & 1.69 & 1.74 \\
cruciform & 1.13 & 1.12 & 1.11 & 1.09 & 1.09 \\
core & 27.52 & 40.34 & 48.65 & 53.98 & 58.54 \\
total & 54.96 & 80.60 & 97.21 & 107.84 & 116.97
\end{tabular}

TABLE II

The contribution of each zone in the BWR system to the integrated heat deposition rate $(\mathrm{MeV} / \mathrm{g})$ for the fuel components $\mathrm{SFG}-\mathrm{PuO}_{2}$.

\begin{tabular}{c|c|c|c|c|c}
\hline \hline \multirow{2}{*}{ Zones } & \multicolumn{5}{|c}{$\mathrm{PuO}_{2}[\mathrm{~mol} \%]$} \\
\cline { 2 - 6 } & 0.2 & 0.4 & 0.6 & 0.8 & 1 \\
\hline fuel & 33.25 & 46.76 & 54.11 & 58.54 & 61.69 \\
water & 3.22 & 3.42 & 3.54 & 3.59 & 3.61 \\
clad & 1.48 & 1.67 & 1.78 & 1.82 & 1.84 \\
cruciform & 1.13 & 1.10 & 1.09 & 1.08 & 1.06 \\
core & 39.16 & 53.04 & 60.60 & 65.13 & 68.31 \\
total & 78.24 & 105.99 & 121.12 & 130.16 & 136.51
\end{tabular}

found that the total heat deposition more than average $12 \%$ in fuel, $7 \%$ in water, $3 \%$ in clad and $2 \%$ in absorbers were released for $0.2-1 \% \mathrm{SFG}-\mathrm{PuO}_{2}$ fuel. In addition to, in Tables I and II was found that heat deposition in the core zone was greater than other zones in the designed BWR system.

In the calculation, it was found that the greatest effect to the $k_{\text {eff }}$, heat deposition rate and fission energy comes with a fuel content of $1 \%$ SFG-PuO ${ }_{2}$.

\section{References}

[1] J. Zakova, J. Wallenius, Ann. Nucl. Energy 58, 255 (2013).

[2] J. Loberg, M. Österlund, K-H. Bejmer, J. Blomgren, Nucl. Sci. Technol. 164, 69 (2010).

[3] J. Loberg, Ph.D. Thesis, Uppsala University, The Faculty of Science and Technology, 2010, p. 715.

[4] R. Fridstrom, Response of The Gamma TIP Detectors in a Nuclear Boiling Water Reactor, UPTEC F10 042, 2010.

[5] IAEA, International Atomic Energy Agency, IAEATECDOC-1349, 2003.

[6] B. Şarer, A. Aydin, M. Günay, M.E. Korkmaz, E. Tel, Ann. Nucl. Energy 36, 417 (2009).

[7] M. Günay, Ann. Nucl. Energy 53, 59 (2013).

[8] M.B. Chadwick, P. Oblozinsky, M. Herman, N.M. Greene, R.D. McKnight, D.L. Smith, P.G. Young, R.E. MacFarlane, G.M. Hale, S.C. Frankle, A.C. Kahler, T. Kawano, R.C. Little, D.G. Madland, P. Moller, R.D. Mosteller, P.R. Page, P. Talou, H. Trellue, M.C. White, W.B. Wilson, R. Arcilla, C.L. Dunford, S.F. Mughabghab, B. Pritychenko, D. Rochman, A.A. Sonzogni, C.R. Lubitz, T.H. Trumbull, J.P. Weinman, D.A. Brown, D.E. Cullen, D.P. Heinrichs, D.P. McNabb, H. Derrien, M.E. Dunn, N.M. Larson, L.C. Leal, A.D. Carlson, R.C. Block, J.B. Briggs, E.T. Cheng, H.C. Huria, M.L. Zerkle, K.S. Kozier, A. Courcelle, V. Pronyaev, S.C. Van der Marck, Nucl. Data Sheets 107, 2931 (2006).

[9] D.B. Pelowitz, MCNPX User's Manual, Version 2.7.0, LA-CP-11-00438, Los Alamos 2011.

[10] I. Akkurt, N. Karpuz, B. Mavi, N. Demir, Ann. Nucl. Energy 65, 181 (2014). 